\title{
Evaluation of industrial parks efficiency for sustainable land use
}

\author{
Vaida Vabuolyte ${ }^{*}$, Marija Burinskienè \\ Department of Roads, Institute of Territorial Planning, Vilnius Gediminas Technical University, Vilnius, Lithuania
}

\begin{abstract}
Implementation of industrial parks had become a worldwide trend in recent decades to promote economic growth and reducing social differences among the regions. However, worldwide examples show that many poor decisions were made in the planning stage. As a result, we have a lot of inefficiently working, obsolescence and even abandoned parks. The purpose of this paper is to analyze the theoretical and applicable aspects of the rational planning of efficiency operating industrial parks. The authors presented the comparative analysis of two industrial parks in Taurage region in term of efficiency. The results proved industrial parks demonstrate better performance (by the number of investors attracted to the park) and have to be developed near major cities to ensure the supply of labor force for developing industries.
\end{abstract}

Keywords: industrial parks, regional analysis, the efficiency of industrial parks, sustainable land use.

\section{Introduction}

Development of industrial parks has been a popular trend for the last decades around the world. Recent studies estimated that nowadays there could be more than 20,000 parks of various types in the world (Salonen, 2010; Sakr, Baas, El-Haggar, \& Huisingh, 2011; Ramos \& Fonseca, 2016). This is a result of policymakers who use industrial zones as one of the main tools to promote economic growth and development as well as reducing social differences among the regions. Social exclusion is one of the high challenges the country of Lithuania is facing constantly. According to the Eurostat database, in the period between 2016-2017, there were $29.6 \%$ of people at risk of poverty or social exclusion in Lithuania. It is more than 7\% higher than the average rate of all European Union (EU) Member States (EUROSTAT, 2019). In 2017th Lithuania approved "Lithuanian Regional Policy White paper for harmonious and sustainable development 2017-2030". The White paper (2017) aim is to develop guidelines for sustainable regional policy and one of the tasks is to encourage implementation of industrial parks among Lithuania regions (National Regional Development Council, 2017).

In perfect conditions, industrial parks look like an ideal solution to the problem presented above. However, in practice, implementing industrial park territory so it would operate efficiency is a challenging task. Creating an industrial park involves considerable investment in land construction, infrastructure, and facilities (Yang, Hao, \& Cheng, 2018). Nevertheless, there are a number of examples around the world how municipalities provided an unreasonable amount of land for industrial area. It is causing a number of problems such as high vacancy rates in parks (Fernandez et al., 2015), obsolescence, deterioration of property and reduced quality of public space as well as low prices on new industrial estates so reinvestment on existing locations are not made (Krabben \& Van Dinteren, 2010) and also urban sprawl (Louw \& Bontekoning, 2007). Unsupported decisions in urban planning lead to investment losses and threaten the emerge of brownfields areas.

This leads to the main purpose of this paper, which is set to evaluate the efficiency of industrial parks. The object of the research is defined to Taurage region in Lithuania. Having an evaluation model can contribute to more sustainable and rational decisions for urban planners and decision-makers in the field of territorial planning.

\section{The efficiency of industrial parks}

In territorial planning documents of Lithuania industrial parks are defined as specific areas, which have developed engineering and communication infrastructure and managed by one operator, and where industrial development investment projects are implemented. In scientific literature terms such as industrial district, industrial estate, industrial zone, business park, free economic zones, science, and technology parks are also widely used. They have some

\footnotetext{
${ }^{*}$ Corresponding author. E-mail: vaida.vabuolyte@vgtu.lt
}

(C) 2019 Authors. Published by VGTU Press. This is an open-access article distributed under the terms of the Creative Commons Attribution (http://creativecommons.org/licenses/by/4.0/) License, which permits unrestricted use, distribution, and reproduction in any medium, provided the original author and source are credited. 
differences in their purpose, size, facilities, organization etc., but are united by common feature as they are all industrial clusters operating in the defined geographical area, managed by a single authority having defined jurisdiction with respect to tenant companies (Phuong, 2002).

Because of the different framework conditions between and within the country, there is no one-size-fits-all model, when talking about the planning of a new industrial park. To maximize the chances of success and efficiency, several strategic decisions must be taken during the planning stage. These include the strategic objectives of the park, financing, the type of companies and sectors that the park wants to attract, and the range of services to be supplied to the tenants (United Nations Industrial Development Organization, 2012).

Different authors generalize three key factors to be considered through the planning process of a new investment project of the industrial park (Table 1).

Table 1. Evaluation factors for the industrial park planning process

\begin{tabular}{|l|l|l|}
\hline \multicolumn{1}{|c|}{ Factor } & \multicolumn{1}{|c|}{ Description } & \multicolumn{1}{|c|}{ Authors } \\
\hline Accessibility & $\begin{array}{l}\text { For people and goods as well as proximity to a port or } \\
\text { an airport, and road/railway transportation to the } \\
\text { infrastructure and the nearest urban center. }\end{array}$ & $\begin{array}{l}\text { Fernández \& Ruiz, 2009; Louw \& } \\
\text { Bontekoning, 2007; UNIDO, } \\
\text { 2012; Ramos \& Fonsecca, 2016 }\end{array}$ \\
\hline Infrastructure and service provision & $\begin{array}{l}\text { For investor security and cleaning services, service } \\
\text { stations, etc. } \\
\text { For the employees' canteen, public transport, etc. }\end{array}$ & $\begin{array}{l}\text { UNIDO, 2012; Fonseca, Ramos, } \\
\text { \& Silva, 2015 }\end{array}$ \\
\hline Acceptable price of land & $\begin{array}{l}\text { In exchange for high investments, employment growth } \\
\text { and for (in)direct taxes on business operations. }\end{array}$ & Du \& Peiser, 2014 \\
\hline
\end{tabular}

It is possible to use these factors not only in the planning process but also for the analysis of the efficiency in the existing industrial park. Additional factors could be also considered:

- Location - it has to ensure the size of the plots as well as a large supply of working force at a reasonable cost (UNIDO, 2012).

- Type of the territory used - brownfield or greenfield area. Parks established in the existing but desolated facilities of former companies are known as brownfields and those developed in new industrial subsectors as greenfield. In Lithuania, most of the state-owned industrial parks, free economic zones, and other estates for industrial purposes are planned in greenfield areas and rarely with reinvestment in brownfields. Brownfield areas had been analyzed in Bielinskas (2018) doctoral thesis. The author points the need for conversion of such areas and suggests 6 possible scenarios for the redevelopment of brownfields. One of the possibilities is to use it for an industrial area. Revitalized brownfield area adds a high value to the surroundings. However, usually, such territory is limited in size in case of the need for an expansion.

- Innovation linkages - a nurturing environment is required to foster vibrant industrial development. Ensuring access to vital services that support innovation and learning is a critical part of establishing such an environment (UNIDO, 2012). For example, science and technology parks require a comfortable linkage with universities as well as other special conditions (green areas, services etc.).

\section{The case of Tauragè region}

Analysis of industrial parks can be performed in a local, regional or national level. For this research, the territorial division has been set to a regional level, which in Lithuania is presented by 10 counties. Since 2010, such division represents only territorial, not an administrative division of the country and equates to regional partitions.

The principle is that 10 regions with three hierarchical centers are formed: the three largest cities (Vilnius, Kaunas, Klaipeda), two intermediate centers (Šiauliai, Panevėžys), and five regional centers (Alytus, Marijampolè, Tauragè, Telšiai, Utena) (Figure 1).

For this analysis of the relatively successful implementation of an industrial park, the example of Taurage industrial park (TIP) has been chosen. TIP demonstrates efficient land usage and sustainable decisions in the built environment as it is established in a mixed brownfield and greenfield area type of land. It is a privately owned industrial park, geographically located in the Southern part of Taurage city. During recent years, in 20 ha territory, TIP has attracted 6 large foreign tenants, who invested more than 40 million Euros and created more than 1,000 of working place. This industrial park can be an example of efficiently operating industrial estate in Lithuania. Several reasons could be the result why is it so? 


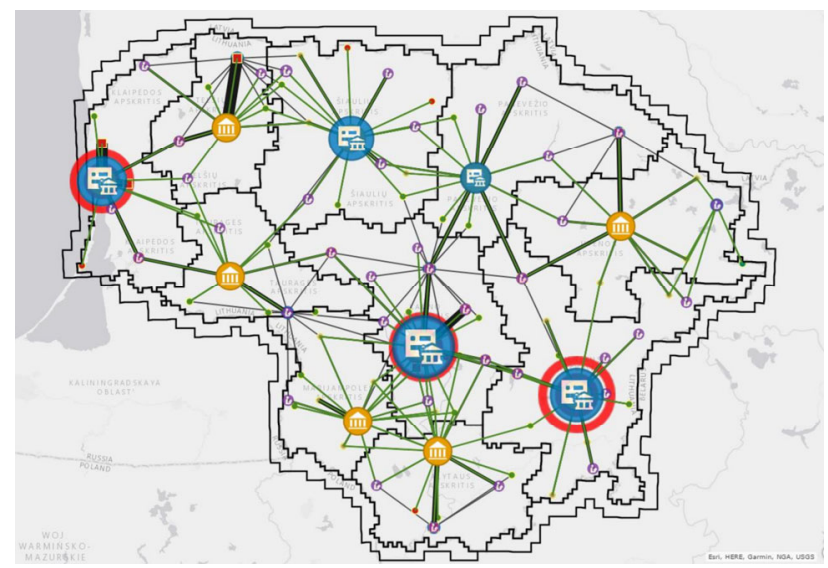

Figure 1. The system of regions and their centers of Lithuania (source: Lithuanian Regional Policy White Paper.., 2017)

\section{Demography}

Although Taurage region is the smallest of all Lithuania regions, in terms of population $(95,817$ people in 2018 by official statistical data of Lithuania), the park itself is located in a strategically good location - the largest municipality as well as the center of the region - Taurage city $(38,921$ people in the district) (Figure 2).

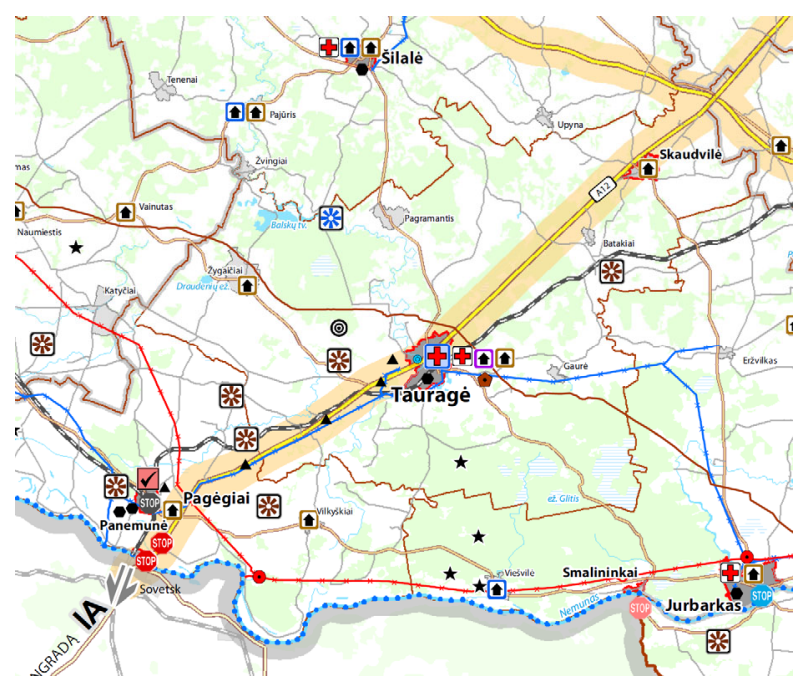

Figure 2. Transport and communication scheme of Taurage district (source: Master plan of Lithuania 2020-2030)

\section{Accessibility}

For the last few years, not only private capital but also city Municipality has invested in industrial areas: bicycle and pedestrian paths, which are very important for the employees, the rainwater system is finished, improving the condition of the roads. In the distance of about $500 \mathrm{~m}$, public transport operates, providing an important connection to the employees to reach the industrial park not only by car but also by a more sustainable kind of transport.

At the global level by car or freight transport, TIP is connected to the international highways - E77 and E85 $(37.4 \mathrm{~km})$. TIP is alongside the Via Hansa route (E77), following its historic intention to connect Germany, Poland, the Russian Federation, Lithuania, Latvia, and Scandinavia.

Compared to most of the regions, Taurage is one of the closest to the ice-free port of Klaipeda - the distance is $111 \mathrm{~km}$. Seaport provides the largest capacity (40,000 tones) on the Baltic coast with ro-ro, cargo and passenger lines to international ports.

By rail transport, it is connected to the railway branch linking the Europe Union with the Eastern markets. Two international airports: Palanga and Kaunas could be reached in less than $160 \mathrm{~km}$, while the biggest Lithuanian airport in Vilnius city, can be reached within $239 \mathrm{~km}$ by road transport.

\section{Environment}

Tauragè region produces green energy from biomass, wind power, hydro energy, and solar systems. The quantity of production in the region is greater than consumed in Taurage. Sustainable - environmental friendly solutions in the regions add value to industrial estates. 
There are two industrial parks in Tauragè region, but another one - Pagègiai industrial park could not be presented as an example of efficient land use for the industrial area (Table 2). Although it has a total area of 30 ha and 0.35 million Eur were invested in the creation of the lots and infrastructure in the greenfield area, the park has not attracted any investment. However, according to the official list of industrial parks and free economic zones provided by Ministry of the Economy and Innovation of the Republic of Lithuania this park exists, in reality, for more than 10 years, since its start in 2008, it has not generated any surplus value.

Some of the reasons for such inefficiency can be location choice as well as a poor demographic situation. Firstly, unless the place has to offer some strong advantages, investors are interested to come to the center of the region, not to the periphery of it. Secondly, the size of the city has to be even more important, as bigger ones can provide an investor with sufficient labor force. For example, the population of Pageigiai municipality was 7,793 people in 2018, which makes it the smallest municipality in the whole region. Considering children and elderly people, which even more reduces the number of working age people, this makes small city uncompetitive compared to major cities in the region.

Table 2. Comparative analysis of industrial parks in Tauragè region

\begin{tabular}{|c|c|c|}
\hline Factor & Tauragè industrial park & Pagègiai industrial park \\
\hline Type of the territory & mixed type: brownfield and greenfield & greenfield \\
\hline Accessibility by road transport & $\begin{array}{l}+ \\
\text { E77 } \\
\text { E85 (37.4 km / } 33 \mathrm{~min})\end{array}$ & $\begin{array}{l}- \\
\text { E77 } \\
\text { E85 (67 km / } 56 \mathrm{~min})\end{array}$ \\
\hline Accessibility to railway & + & + \\
\hline Accessibility to airport & $\begin{array}{l}+ \\
\text { Kaunas } 154 \mathrm{~km} / 1 \text { h } 44 \mathrm{~min} \\
\text { Vilnius } 241 \mathrm{~km} / 2 \text { h } 36 \text { min } \\
\text { Palanga } 143 \mathrm{~km} / 1 \text { h } 43 \mathrm{~min}\end{array}$ & $\begin{array}{l}- \\
\text { Kaunas } 184 \text { km / } 2 \text { h } 6 \text { min } \\
\text { Vilnius } 270 \text { km / } 2 \text { h } 59 \text { min } \\
\text { Palanga } 118 \text { km / } 1 \text { h } 39 \text { min }\end{array}$ \\
\hline Accessibility to Klaipeda seaport & $\begin{array}{l}- \\
116 \mathrm{~km} / 1 \mathrm{~h} 25 \mathrm{~min}\end{array}$ & $\begin{array}{l}+ \\
90 \mathrm{~km} / 1 \mathrm{~h} 22 \mathrm{~min}\end{array}$ \\
\hline $\begin{array}{l}\text { Demographic situation of the } \\
\text { municipality }\end{array}$ & $\begin{array}{l}++ \\
38.921\end{array}$ & $\begin{array}{l}- \\
7.793\end{array}$ \\
\hline Operator & Private & Public \\
\hline Investors & $\begin{array}{l}+ \\
6\end{array}$ & $\begin{array}{l}- \\
0\end{array}$ \\
\hline
\end{tabular}

*Pluses and minuses system represents not the presence and absence of certain indexes, but better value in terms of corresponding meanings.

Finally, TIP is set up by a private capital initiative and managed by private operator accordingly to pay off. For this reason, the results of similar business structures in the same region can be fundamentally different.

\section{Discussion and conclusions}

Example of industrial parks in Lithuania exposed that not every industrial park can be attractive to investors. Analysis of Taurage region and its industrial parks sustains the theory, that industrial parks demonstrate better performance results and have to be developed near bigger cities. To define the minimum limit of the size, more detailed research needs to be continued. Comparative analysis of 2 industrial parks in the same regions proved that demographic situation - labor force and location of the city are important for attracting investors and for the efficient operation of the park. TIP also presents slightly better accessibility results to major airports as well as road transport.

The analysis of TIP provided insights that similar business structures in the same region can perform fundamentally different depending also on the management type - if it is private or public. In case of a private operator of the industrial park, the private-public partnership is still very important. Making not only industrial park, but also surrounding areas well-developed in terms of quality infrastructure and public services for the investor and its employees is another factor, which adds value to the attraction of the investments to the park and adds benefits to the municipality itself.

Proposing project implementation of new industrial parks has to be analyzed in term of its possible efficiency. This can help municipalities and other decision-makers avoid faulty investments and also waste of environmental resources. Choosing the territory for a new industrial park, the possibility of reinvestment and redevelopment of 
brownfield areas is highly advisable too. Sustainable - environmental friendly solutions, such as usage of green energy in the regions also add value to industrial zones.

This paper is also an entry presentation of doctoral research in the analysis and sustainable development of industrial parks for the revitalization of regions in Lithuania. Evaluation of the efficiency of the industrial parks in all regions will continue. Applying statistical, GIS analysis, MCDM and other methods, the best industrial parks types by different types of territory, smart specializations of regions, and other criterions will be suggested for possible implementation scenarios.

\section{References}

Bielinskas, V. (2018). Miesto apleistu teritoriju paskirties keitimo scenariju vertinimas daugiarodikliais sprendimu prièmimo metodais. Vilnius: Technika. https://doi.org/10.20334/2019-001-M

$\mathrm{Du}$, J., \& Peiser, R. (2014). Land supply, pricing and local governments' land hoarding in China. Regional Science and Urban Economics, 48, 180-189. https://doi.org/10.1016/j.regsciurbeco.2014.07.002

EUROSTAT. (2019). People at risk of poverty or social exclusion. Retrieved from https://ec.europa.eu/

Fernandez, C., Weyman, T., Fol, S., Audirac, I., Sabot, E., Wiechmann, T., \& Yahagi, H. (2015). Shrinking cities in Australia, Japan, Europe and the USA: From a global process to local policy responses. Progress in Planning, 105, 1-48. https://doi.org/10.1016/j.progress.2014.10.001

Fernández, I., \& Ruiz, M. (2009). Descriptive model and evaluation system to locate sustainable industrial areas. Journal of Cleaner Production, 17, 87-100. https://doi.org/10.1016/j.jclepro.2008.02.011

Fonseca, F., Ramos, R., \& Silva, A. (2015). An agent-based model to assess the attractiveness of industrial estates. Journal of Artificial Societies and Social Simulation, 18(4), 13. https://doi.org/10.18564/jasss.2893

Krabben, E., \& Van Dinteren, J. (2010). Public development of industrial estates in the Netherlands: Undesired market outcomes and policy interventions. Tijdschrift voor Economische en Sociale Geografie, 101(1), 91-99. https://doi.org/10.1111/j.1467-9663.2009.00589.x

Louw, E., \& Bontekoning, Y. (2007). Planning of industrial land in the Netherlands: Its rationales and consequences. Tijdschrift voor Economische en Sociale Geografie, 98(1), 121-129. https://doi.org/10.1111/j.1467-9663.2007.00380.x

National Regional Development Council. (2017). Lithuanian Regional Policy White Paper for harmonious and sustainable development 2017-2030.

Phuong, P. T. (2002). Ecological modernisation of industrial estates in Viet Nam. Wageningen University.

Ramos, R. A. R., \& Fonseca, F. P. (2016). A methodology to identify a network of industrial parks in the Ave Valley, Portugal. European Planning Studies, 24(10), 1844-1862. https://doi.org/10.1080/09654313.2016.1202201

Sakr, D., Baas, L., El-Haggar, S., \& Huisingh, D. (2011). Critical success and limiting factors for eco-industrial parks: Global trends and Egyptian context. Journal of Cleaner Production, 19, 1158-1169. https://doi.org/10.1016/j.jclepro.2011.01.001

Salonen, T. (2010). Strategies, structures and processes for network and resources management in industrial parks: The case of Germany and China. Leipzig: Verlag.

Yang, Z., Hao, G., \& Cheng, Z. (2018). Investigating operations of industrial parks in Beijing: efficiency at different stages. Economic Research-Ekonomska Istraživanja, 31(1), 755-777. https://doi.org/10.1080/1331677X.2018.1442235

United Nations Industrial Development Organization (UNIDO). (2012). Europe and Central Asia regional conference on industrial parks as a tool to foster local industrial development (Conference report). Baku, Azerbaijan. 